\title{
THE EFFECT OF ENVIRONMENT CONTROL, RISK ASSESSMENT AND MONITORING ON THE PREVENTION OF FRAUD (A SURVEY AT DINAS PENDIDIKAN ACEH PROVINCE)
}

\author{
Muyassir Kahar*1, M. Rizal Yahya $^{* 2}$ \\ ${ }^{1,2}$ Program Studi Akuntansi Fakultas Ekonomi dan Bisnis Universitas Syiah Kuala \\ e-mail: muyassir.kahar@gmail.com ${ }^{* 1}$,rizal_yahya@ unsyiah.ac.id ${ }^{* 2}$
}

\begin{abstract}
The purpose of this research is to examine the effect of environment control, risk assessment, and monitoring on the prevention of fraud at Dinas Pendidikan Aceh Province. The population of this research is all employees at Dinas Pendidikan Aceh Province which totaling 337 employees ( respondents). The sample method that will be used for this study is simple random sampling. Data collection techniques were conducted with questionnaires. The results of this research shown that simultaneously and partially, the environment control, risk assessment, and monitoring affected on the prevention of fraud at Dinas Pendidikan Aceh Province.
\end{abstract}

\section{Keywords: Environment Control, Risk Assessment, Monitoring, fraud Prevention}

\section{Introduction}

Many organizations of any type, shape, scale of operations, and activities are at risk of fraud. Fraud will provide benefits for those who do it, but the impacts are very harmful to the company and the performance of organizations. The rise of news about the investigation of indications of fraud irregularities within the company and also the management of the state, the more aware that we as the nation's generation must make changes to overcome the problem of it. Although today the main focus is often on high-level officials of an agency, but actually these behavioral deviations can also occur in various positions of organizational performance.

Various media including newspapers, television and the Internet often proclaim the events regarding an indication of fraud in a company or government agency that is committed by employees. The main highlights of these topics is directed at highranking official of a government agency, but in fact the deviant behavior can also occur in various layers of the organization's work. Fraud and decline in performance of employees can occur due to the motivation in the employees

Governance as the trust of the community has an obligation to perform its duties effectively and efficiently, one of which is ensuring that state finances are well managed and accountable. Within the scope of government entities, finansial statements are a means of communication and a form of accountability to the public. Therefore, the financial statements in government entities are closely related to the public interest so that the figures listed in the financial statements should show actual figures. Of course, in realizing these goals and to minimize fraud must be supported by the behavior or good actions of its employees.

Karyono (2003) basically, the fraud is a social parasite which damages the structures of government, and the main obstacle to the running of the government and development in general. In general fraud is an unlawful act perpetrated by persons from within and/or outside the organization, with the intention of obtaining personal gain or group which directly harms the other party. Razaae (2002) suggests that fraud may consist of various forms of crime or white-collar crime, such as theft, asset fraud, embezzlement of information, embezzlement of liabilities, omission or concealment of facts, including corruption.

Fraud can occur in various sectors, both in the private sector and in the government sector. The case of fraud that often occurs in every agency is a case of corruption. In government agencies, corruption cases involve not only those who have high positions but also those below them.

In Indonesia, cases of fraud is still relatively high so it make the lack of public convidence to the 
government. Based on the findings of (TI) Transparency International in the (CPI) Corruption Perception Index 2016, that Indonesia's CPI score of 37 and ranks 90th of 176 countries measured, Scores Indonesia up 1 point from the previous year. CPI scores are in the range $0-100$, score 0 means that the perceived state is very much corrupt, while a score of 100 means perceived very clean Skor.

Indonesia Corruption Watch, Wana Alamsyah (2016) The cases of fraud that occurred in government agencies, especially in the educational world is now incresingly occurs. Cases of corruption in the education sector are the most widely prosecuted by law enforcers from 2005 to 2016. There are 335 suspected in Dinas Pendidikan empoyees, 95 suspected in private sector, 77 suspected in Head of Department, 65 suspected in head of school and 27 suspected in treasurer. The total of suspected are 618 and 425 cases with total amount $\mathrm{Rp} 1.3$ Billion. Suspects in corruption cases involve heads of departments and staff, members of the DPR/DPRD, ministry officials, teachers, heads of school, lecturers, and rectors.

As in case with the Dinas Pendidikan Abdya, according to trusted sources in 2018 there has been corruption of E-Learning (ICT) procurement, in procurement projects in the Dinas Pendidikan Abdya sourced from Otsus and resulted in state losses of $\mathrm{Rp}$ 293 million.

From the above phenomenon it can be seen that there is fraud in an organization that involves people in an entity. This is caused by the existence of opportunities and weak internal control of the organization, the possibility of errors, inaccuracies or fraud in the organization is very large.

Furthermore, environmental control sets the spirits of an organization that influences the awareness of the control of the employee. The control environment is the foundation of all other internal control components that provide discipline so that it can sustain the fraud.

COSO (1992) The environment control sets the tone of organization, influencing the control consciousness of its people. It is the foundation for all other componets of internal control, providing discipline and structure. The environment control factors include the integrity, ethical values and competence of the entity's people, management's philosophy and operating style, the way management 20 assigns authority and responsibility, and organizes and develops its people, and attention and direction provided by the board of directors.

Ramos (2004), The environment control has an entrenched structure that affects most business process activities including elements of management integrity and ethical values, operating style and management philosophy, delegation of authority and responsibility. The control effectiveness depends on the management attitude. If top management believes that control is important, then all the elements in the organization will see it the same. Conversely, it becomes ineffective when top management assumes that control is unimportant and merely as a symbol or to comply with the conditions. Here demanded the competent people, who understand responsibilities and limitations of their authority, have a commitment in adherencing the policies and ethical standards of organizational behavior. Management and all employees should create and maintain environment within the entire organization that leads to a positive and supportive behaviors towards healthy internal controls (conscientious). It is also affirmed by The Institute of Internal Auditors that "Controls are everybody's business". This means the entire organization, and each person who works there, should be "tune in" to internal control.

Then, all of the organization certainly has risks. In any conditions the risk must exist in an activity, both business and non-business activities (profit or non profit). A risk that has been identified can be analyzed and evaluated so as to estimate the intensity and actions that can minimize it. Risk assessment for financial reporting purposes is the identification of the analysis and risk management of an entity relevant to the preparation of the financial statements that are presented fairly in accordance with generally accepted accounting principles. In addition, risk assessment in determining audit object is very important. Because in according to the functions and role of internal audit is now entering a new paradigm from its traditional role as a police officer or party tends to find fault with others in the organization.

Monitoring involves design assessment, and proper operation of controls and take corrective action required by the company. The company needs a strong monitoring mechanism so that the leaders become 
more confident that all elements of the company are running as expected. Through continuous monitoring, leaders will have updated information as a basis for decision making. Monitoring is an effective way to improve other internal control elements. From the monitoring will be identified the weakness of the existing system, the portrait of weakness is then become the material to formulate recommendations for improvement for weak control elements. Thus, through automatic monitoring there will be improvement of all elements of internal control.

Essentially, the governments want all representatives of the people to behave honestly. Therefore, the government, together with its institutions, should try to prevent fraud in the government sector. It is expected with this research, it can provide information to the public about the magnitude of influence with the existence of environment control, risk assessment, and monitoring of fraud prevention in the Education Departments.

Based on the above description of the background, the purpose of this research is to test the effect of environment control, risk assessment \& monitoring on the prevention of fraud. The results of this research are expected to give the benefit for many parties, including for academics and the Government.

\section{Literature Review And Hypothesis Development \\ Literature Review \\ Fraud Prevention}

Black'slaw dictionary fraud (1996), describes the understanding of fraud is encompassing all sorts of human minds, and attempted by, to gain benefit from others by false suggestions or coercion of truth, and encompasses all unexpected ways, cunning, hidden, and every dishonest way that causes others to be deceived. Briefly, it can be said that fraud is a cheating which is related to a sum of money or property.

Alison (2004) states, fraud as a form of deceit that causes unnoticed losses by the injured party and provides benefits for the perpetrators of fraud. Fraud generally occurs because of the pressure to abuse or the encouragement to utilize the opportunities and justification (generally accepted) of the action.

Kurniawati (2012), (ACFE) Association of Certified Fraud Examinations is one of the associations in the USA which has major activities in the prevention and eradication of fraud. According to The ACFE there are three categories of frauds, namely:

1. Financial Statement Fraud

Fraudulent Financial Statements can be defined as fraud did by management in the form of material misstatements of Financial Statements that are injurre investors and creditors. This can be financial or non-financial fraud.

2. Asset Abusement

Asset abusement can be classified into Cash Fraud and Other Inventories and Assets Fraud, as well as fraudulent disbursement.

\section{Corruption}

Corruption is devided to conflict of interest, bribery, illegal gratuity, and economic extortion. This type of fraud is symbiotic mutualism, it is often undetected because related parties enjoy the profit together.

Facing the possibility of fraud, the act of a good and easy way is to try to avoid or prevent fraud itself. (COSO in Sofianingsih 2014) Fraud prevention in general are activities carried out management in terms of establishing policies, systems and procedures that help ensure that the necessary measures have been carried out of the board of directors, management and other personnel in the company to be able to provide adequate confidence in achieving three (3) main objectives are: reliability of financial reporting, effectiveness and efficiency of operations and compliance with applicable laws \& regulations.

According to the Internal Audit Education Foundation (2008: 14) mentioning prevention of fraud can be done by:

1. Build, maintain and protect mental / moral officers to always be honest, disciplined, loyal, ethical and dedicated.

2. Establish an internal control system mechanism that is efficient and effective through:

a. Apply the better internal control, good control environment, good accounting system, good control procedure.

b. Pressing on the emergence of collusion with the Vacation system, transfer jobs (tour of duty) or leave.

c. Reminding outside parties (Vendor and contractor) to be aware of kickback and various types of giving, that the company 
has "right to audit".

d. Monitor continuous implementation of employee duties.

e. Creating a Hotline system: every employee or other person can complain of symptoms of cheating.

f. Providing appropriate penalties for the perpetrators of implementing Proactive fraud auditing.

The above methods of fraud prevention are the responsibility of management. Which is expected to reduce the amount of fraud in the body of a company through the maintenance and implementation of the system and cultural values that are required by a company.

\section{Environment Control}

Guy et al (2002) explains the environment control determines the quality of the entity by influencing the awareness of control of people around. The environment control reflects the overall attitudes, awareness, and actions of the Board of Directors, management, employees, and others regarding the importance of such control and the emphasis it places on an entity. It is the foundation of the discipline and structure of all other internal control components.

\section{Risk Assessment}

Risk assessment is the identity, analysis and risk management of the entity which is relevant to the preparation of the financial statements which fairly presented in accordance to generally accepted accounting principles. The entity's risk assessment process should notice the internal and external circumstances which have potential to greatly affect its ability in record, process and report financial data which consistent with management assertions in the financial statements. Risk assessment should also aware to risks arising from several conditions, it consist of risk identification and risk analysis.

\section{Monitoring}

Monitoring is a process that assesses the quality of internal control performance at a time. Monitoring can be done through continuous activity or separate evaluation. Continuous monitoring procedures are applied on normal routine activities occurring within an entity also covers management activities and supervisory activities.

\section{Theoritical Framework}

The framework of this research aims to explain the influence of the independent variables, namely: Environment Control (X1), Risk Assessment (X2), and Monitoring (X3) on the dependent variable, namely: Fraud Prevention (Y).

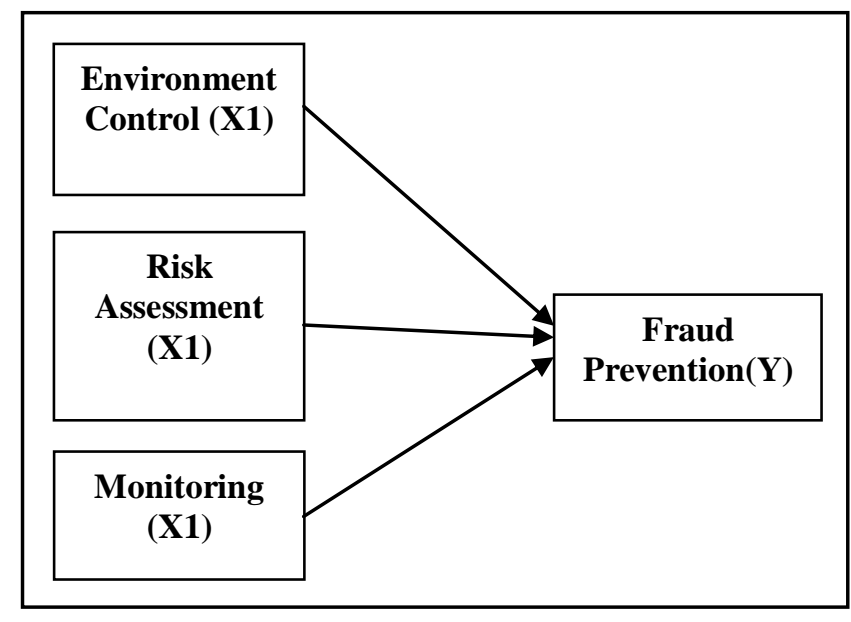

\section{Hypothesis Development}

H1: Environment Control is affected on fraud prevention.

$\mathrm{H} 2$ : Risk Assessment is effected on fraud prevention

H3: Monitoring is affected on fraud prevention.

H4: Environment Control, Risk Assessment and Monitoring are affected on fraud prevention.

\section{Research Methodology}

\section{Research Population and Sample}

In this research, the population is at Dinas Pendidikan Aceh. The sample method that will be used for this study is simple random sampling with the amount of sample determined by using formula based on Slovin Theory.

$$
\begin{aligned}
& n=\frac{N}{1+N \cdot e^{2}} \\
& n=\frac{337}{1+337(0,1)^{2}} \\
& n=77.12
\end{aligned}
$$

So, the target minimum sample is 77.12 or 77 .

\section{Data Collection Method}

The data used in this study is the primary data. Primary data means the data obtained is from the first 
source, for example from individuals/person (Sekaran, 2006: 75). Primary data was obtained from field research by distributing questionnaires. The questionnaire is delivered directly to the respondent and give them time to fill it. The answers of the questionnaire will be collected by the researcher according to the time agreed by the respondent.

\subsection{Variable Operationalization}

\begin{tabular}{|c|c|c|}
\hline Variabel & Indicator & Source \\
\hline $\begin{array}{l}\text { Fraud Prevention } \\
\text { (Y) }\end{array}$ & $\begin{array}{l}\text { 1. Pressure } \\
\text { 2. Opportunity } \\
\text { 3. Rationalization } \\
\text { 4. Ability }\end{array}$ & $\begin{array}{l}\text { Wolfe dan } \\
\text { Hermanso } \\
\text { n (2004) }\end{array}$ \\
\hline $\begin{array}{l}\text { Environment } \\
\text { Control }\left(\mathrm{X}_{1}\right)\end{array}$ & $\begin{array}{ll}\text { 1. Integrity and ethical } \\
\text { values } \\
\text { 2. } \begin{array}{l}\text { Commitment } \\
\text { towards competency }\end{array} \\
\text { 3. Participation of } \\
\text { Board Directors and } \\
\text { Audit Committee } \\
\text { 4. Operation style and } \\
\text { management } \\
\text { philosophy } \\
\text { 5. Organizational } \\
\text { structure } \\
\text { 6. Delegation of } \\
\text { authority and } \\
\text { responsibility a its } \\
\text { 7. Policy and its } \\
\text { application }\end{array}$ & $\begin{array}{l}\text { Guy et al, } \\
\text { (2002) }\end{array}$ \\
\hline $\begin{array}{l}\text { Risk Assessment } \\
\left(\mathrm{X}_{2)}\right.\end{array}$ & $\begin{array}{ll}\text { 1. } & \text { Risk Assessment } \\
\text { 2. } & \text { Leaders Concern } \\
\text { 3. } & \text { Risks Anticipation } \\
\text { 4. } & \text { Risk Analysis }\end{array}$ & $\begin{array}{l}\text { Putri } \\
(2013)\end{array}$ \\
\hline Monitoring $\left(\mathrm{X}_{3}\right)$ & $\begin{array}{lll}\text { 1. } & \text { Monitoring by } \\
& \text { SKPD } & \text { by } \\
\text { 2. } & \text { Follow-up and } \\
\text { recommendation } & \\
\text { regarding } & \text { the } \\
\text { findings } & \\
\text { 3. } & \text { Review } & \text { and } \\
& \text { evaluation } & \\
& \text { Follow-through } & \\
& \text { action } & \\
\end{array}$ & $\begin{array}{l}\text { Putri } \\
(2013)\end{array}$ \\
\hline
\end{tabular}

Sumber: Data diolah (2018)

\section{Analysis Method}

$$
\mathbf{Y}=\alpha+\beta_{1} \mathbf{X}_{1}+\beta_{2} X_{2}+\beta_{3} X_{3}+\varepsilon
$$

Explanation:

$\begin{array}{cl}\mathrm{Y} & : \text { Fraud } \\ \mathrm{A} & : \text { Constant } \\ \beta & : \text { Regression coefficient } \\ \mathrm{X}_{1} & : \text { Environment Control }\end{array}$

$\begin{array}{ll}\mathrm{X}_{2} & \text { : Risk Assessment } \\ \mathrm{X}_{3} & \text { : Monitoring } \\ \varepsilon & : \text { Error }\end{array}$

\section{Result And Discussion}

\section{Respondents Characteristics}

Respondents characteristic in this research are classified based on gender, age, level of education, education department, and years of service. From 77 respondents, the most respondents were male with 43 respondents (55.8\%) and the respondents aged 30-39 years was the highest with 34 respondents (44.1\%). For the level of education, Bachelor degree was highest with 40 respondents (51.9). Based on education department, the highest was 39 respondents $(50.6 \%)$ in the field of accounting and the most respondents with 6-15 years of service was the highest with 39 respondents (50.6).

\section{Multiple Linear Regression Result}

Based on the results of statistical calculations using the SPSS program, the following multiple linear regression equations are obtained as follows:

$$
Y=0,782+0,267 X_{1}+0,403 X_{2}+0,203 X_{3}+e
$$

From the regression equation, it can be seen that the results of each coefficient are for constants $(\mathrm{a}=$ 0.782), meaning that if Environment Control (X1), Risk Assessment (X2), And Monitoring (X3) is considered constant, then the magnitude of the Fraud Prevention is 0.782 .

The regression test results for the first hypothesis in this study were conducted to find out whether the environment control has an effect on fraud prevention. The results show a significance value of 0.009 smaller than alpha $5 \%$ or 0.05 . It means the environment control has effect on fraud prevention because of the sig value less than 0.05 .

Regression test results for the second hypothesis in this study were conducted to know whether the risk assessment has an effect on fraud prevention. The test results show a significance value of 0.000 smaller than alpha $5 \%$ or 0.05 . It means that risk assessment affects Fraud prevention because of the value of sig. below 0.05 .

The regression test results for the third hypothesis in this study were conducted to know 
whether monitoring has effects on fraud prevention. The result shows a significance value of 0.019 smaller than alpha $5 \%$ or 0.05 . It means that monitoring affects the fraud prevention due to the sig value less than 0.05 .

The regression test results for the fourth hypothesis in this study were conducted to know the environment control, risk assessment, and monitoring simultaneously effect on fraud prevention. The results simultaneously show a significance value of 0,000 smaller than alpha $5 \%$ or 0.05 . The results of the study show that the environment control, risk assessment, and monitoring simultaneously affected fraud because of the sig value. below $5 \%$.

The determination coefficient (R2) is 0.537 . This means that the environment control, risk assessment, and monitoring are able to explain the variation of the fraud prevention variable by $53.7 \%$ while the remain $46.3 \%$ is explained by other variables which are not included in this research variables.

\section{Discussion}

\section{The Effect of Environment Control on The Prevention of Fraud}

The partial test results showed that the regression coefficient $\beta 1$ is 0.267 with a significance value of 0.009 . This means that the environment control affects fraud prevention. The coefficient of 0.267 means that if the environment control rises by 1 unit then fraud prevention will increase by 0.267 units. That means with a better environment control, the fraud prevention will be better.

Without an effective environment control, the other four components might not produce the effective internal control. The control environment serves as an umbrella for the other four internal control components. A conductive control environment can encourage the role of internal auditors to quickly establish action plans for fraud prevention programs, and will get ways to add value to their organizations.

\section{The Effect of Risk Assessment on The Prevention of Fraud}

The partial test results showed that the regression coefficient $\beta 2$ is 0.403 with a significance value of 0.000 . This means risk assessments affected the fraud prevention. The coefficient of 0.403 means if the risk assessment rises by 1 unit then fraud pevention will increase by 0.403 units, that mean with a better risk assessment, the fraud prevention will be better.

Management risk assessment should consider the risks arise a number of conditions, including risk identification and risk analysis. Risk identification includes testing of external factors such as technological developments, competition, and economic change. While, Internal factors include employee competence, the nature of business activities, and the characteristics of the information system management. Whereas Risk Analysis involves estimating significant risks, assessing the possibility of risk occurrence and how to manage risk.

\section{The Effect of Monitoring on The Prevention of Fraud}

The partial test results indicate that the regression coefficient $\beta 3$ is 0.203 with a significance value of 0.019 . This means that monitoring has an effect on fraud prevention. The coefficient of 0.203 means that if monitoring increases by 1 unit then fraud prevention will increase by 0.203 units. That means with a better monitoring, the fraud prevention will be better.

The research conducted by Erika in 2017 showed that Ineffective monitoring has a positive and significant effect on the occurrence of fraud partially. This proves that the higher the Ineffective Monitoring, the higher the occurrence of Fraud in the Cooperative. Financial targets and ineffective monitoring simultaneously have a significant effect on the occurrence of fraud. So that if financial targets and ineffective monitoring simultaneously increase, the occurrence of fraud will also increase. Then can be concluded that the greater Financial Targets and Ineffective Monitoring are, the greater the occurrence of fraud.

\section{The Effect of Environment Control, Risk Assessment, and Monitoring on The Prevention of Fraud}

The results showed that environment control, risk assessment, and monitoring simultaneously affected the fraud prevention. This also showed that fraud prevention was simultaneously determined by encironment control, risk assessment, and monitoring. 


\section{Conclusion And Suggestion}

Based on the results of the study, the following conclusions are obtained as follows:

1. Environment control affects the fraud prevention.

2. Risk assessment affects the fraud prevention.

3. Monitoring affects the fraud prevention

4. Environment control, risk assessment, and monitoring simultaneously affected fraud prevention.

There are some limitations that the researcher would like to acknowledge in this study. Those limitations are described below:

1. This study uses only three independent variables, while actually there are still many other variables out there that might influence the practice of prevention to fraud.

2. The object used in this study only in Dinas Pendidikan department, so that the results of this study cannot be used as a generalization to different Departments.

\section{References}

Alison. 2004. Fraud Auditing. The Internal Audit Journal.

Brooks, Leonard J dan Paul Dunn. 2012. Business and Profesional Ethics for Directors, Executive and Accountans. Edisi 6, Mason City: SouthWestern Cengage Learning.

Cressey, D. (1953). Other People's Money. Monclair, NJ: Patterseon Smith, pp. I-300.

Duwi Priyatno, 2010. Teknik Mudah dan Cepat Melakukan Analisis Data Penelitian dengan SPSS dan Tanya Jawab Ujian Pendadaran. Gaya Media, Yogyakarta.

Guy, Dan M.,et al. 2002. Auditing. Edisi Kelima. Jilid II. Penerjemah Sugiyarto. Jakarta: Erlangga.

Karyono. 2013. Forensic Fraud, First Edition. Yogyakarta: ANDI.

Kurniawati, Ema. 2012. Analisis Faktor-Faktor yang Mempengaruhi Financial Statement Fraud dalam Perspektif Fraud Triangle. Jurnal Apresiasi Ekonomi. Vol. 01 No. 04.

Ramos, Michael. 2004. "Evaluate The Control Environment".http://www.aicpa.org/PUBS/jofa/ may2004/ramos.htm.

Rezaee, Z, 2002. Financial Statement Fraud: Prevention and Detection. New York: John Wiley \& Sons, Inc..

Sekaran, Uma. 2006. Metodelogi Penelitian untuk Bisnis. Fourth Edition. Jakarta: Salemba Empat.
Thomas, G. N., and Metrejean, E. (2013). The Importance of The Constrol Environment: Expense Account Fraud At Blue Grass Airport. Journal of Business \& Economic Research. Vol 11 No 2: 97-106.

Wolfe, David T.; Hermanson, Dana R. 2004. The Fraud Diamond: Considering the Four Elements of Fraud. CPA Journal; Dec2004, Vol. 74 Issue $12, \mathrm{p} 38$. 